\title{
Taste Thresholds of Phenylthiocarbamide and 6-n-Propylthiouracil and their Correlation with TAS2R38 Genotype
}

\author{
Sung Yong Choi, Seung Heon Shin and Mi Kyung Ye \\ Department of Otorhinolaryngology-Head and Neck Surgery, Catholic University of Daegu School of Medicine, Daegu, Korea
}

\begin{abstract}
Phenylthiocarbamide와 6-n-Propylthiouracil을 이용한 미맹 검사와 유전자형의 일치 정도의 분석
\end{abstract}

최성용 · 신승헌 · 예미경

대구가톨릭대학교 의과대학 이비인후과학교실

Received May 20, 2010

Revised July 12,2010

Accepted July 15, 2010

Address for correspondence

Mi Kyung Ye, MD

Department of Otorhinolaryngology-

Head and Neck Surgery,

Catholic University of Daegu

School of Medicine,

3056-6 Daemyeong 4-dong, Nam-gu,

Daegu 705-718, Korea

Tel +82-53-650-4525

Fax +82-53-650-4533

E-mail miky@cu.ac.kr
Background and Objectives Phenylthiocarbamide (PTC) and its chemically related compound, 6-n-propylthiouracil (PROP), both produce a taste that is extremely bitter to some subjects (tasters) but tasteless or only slightly bitter to others (non-tasters). Earlier studies had used PTC, but most investigators have switched to PROP because of its several advantages. Recently, three single nucleotide polymorphisms in the TAS2R38 gene were identified and several studies have demonstrated a strong association between these genes with taster status. The aim of this study was to investigate the relationship between taste thresholds of PTC and PROP and their correlation with the TAS2R38 genotype.

Subjects and Method Seventy-five healthy normal volunteers were included. Taster status was determined using successive solutions of PTC and PROP, which comprised a total of 15 grades. All participants were genotyped for polymorphism of the TAS2R38 gene that affects taste sensitivity to PTC and PROP.

Results PTC taste thresholds showed $96 \%$ correlation with the taste thresholds for PROP. Non-tasters defined by the PTC threshold test were the exactly the same with those identified as AVI (alanine, valine, isoleucine) homozygous, but taster status determined by the PROP threshold test showed $96 \%$ correlation with the genotypes.

Conclusion The PTC threshold test was more reliable for determining taste blindness than the PROP threshold test. Korean J Otorhinolaryngol-Head Neck Surg 2010;53:547-51

Key Words Taste $\cdot$ Genetics $\cdot$ Phenylthiocarbamide.

\section{서 론}

미맹이란 phenylthiocarbamide(PTC)라는 합성 화합물 질의 쓴맛을 느끼지 못하는 사람을 말하며, 인종에 따른 차이가 있으나 전 인구의 10 30\% 가 해당한다. ${ }^{1)}$ 초기 연구 에는 예외 없이 PTC를 이용하여 미맹검사를 하였으나, 같 은 $\mathrm{N}-\mathrm{C}=\mathrm{S}$ 구조를 가진 6-n-propylthiouracil(PROP) 이 맛 반응이나 전기생리 반응이 PTC와 거의 유사하며, ${ }^{2-4)}$
더 안전하다는 장점으로 인하여 PTC를 대체하게 되었다. ${ }^{3,5,6)}$ 그러나 Bufe 등 ()은 저농도에서는 양 물질 간의 차이가 거 의 없으나 고농도에서는 차이가 나므로 $\mathrm{PROP}$ 가 PTC의 완전한 대용품이 될 수 없다고 하였다. PTC 미맹 검사는 가장 오래된 인류의 화학감각에 대한 유전학적 검사로 다른 물질로 대체되는 것은 아주 중요한 변화를 의미한다. 그럼 에도 불구하고 아직까지 국내에서는 PTC 및 $\mathrm{PROP}$ 미맹 검사의 일치율에 대한 보고가 없는 실정이다. 
최근 분자생물학적 기법의 발달에 힘입어 TAS2R38 유 전자에 세 개의 single nucleotide polymorphism(SNP)을 발견하였으며, 이 유전자 변이가 PTC 맛 감지 다양성의 55 $85 \%$ 를 설명한다는 보고가 있다. ${ }^{8)}$ 이 유전자의 $\mathrm{SNP}$ 의 조 합으로 생성된 일배체형(haplotype) 들은 아미노산 변화에 따라 이름을 붙여 부르며, 가장 많은 일배체형은 PAV (proline, alanine, valine)와 AVI(alanine, valine, isoleucine)의 두 가지 형태이다. ${ }^{8-10)}$ 미맹인은 유전자형이 AVI/AVI 동종접 합형, 미각인은 $\mathrm{PAV} / \mathrm{PAV}$ 동종접합형이나 PAV/AVI 이종 접합형으로, 표현형과 유전자형 간에 밀접한 관계가 있다고 보고되었다. ${ }^{11)}$ 그러나 PTC 및 $\mathrm{PROP}$ 에 대한 미맹 여부와 유전자형과의 일치 정도에 대한 연구는 국내 뿐만 아니라 해외에서도 거의 없다.

본 연구는 $\mathrm{PTC}$ 와 $\mathrm{PROP}$ 를 이용한 미맹 검사의 일치율 을 분석하고, 또한 각각의 검사와 미맹 유전자형과의 일치 정도도 비교하고자 하였다.

\section{대상 및 방법}

\section{대 상}

자원자 모집 광고를 통해 모집된 19 세 이상의 정상 성인 남녀 75명을 대상으로 하였다. 남자 40명, 여자 35명이었 으며, 평균 연령은 35.3 세였다. 본 연구는 임상시험윤리위 원회의 승인을 받아 진행되었다. 모든 대상에서 미각 검사 및 미각 유전자 분석 연구에 대한 동의서를 받았고, PTC와 $\mathrm{PROP}$ 를 이용한 미맹검사와, TAS2R38 유전자에 대한 분 석을 시행하였다.

\section{미맹검사}

기준 농도의 설정은 Harris 등 ${ }^{12)}$ 의 방법을 참고로 하였 으며, PTC(Sigma-aldrich, Inc., St. Louis, USA)를 17 $\mathrm{mM}(2.584 \mathrm{gm} / \mathrm{L})$ 농도로 증류수에 녹인 후 용액 15번으 로 하였다. 증류수로 2 배수 희석하여 총 15 단계의 용액을 만들었으며, 가장 약한 농도인 1 번 용액은 $1.0 \times 10^{-6} \mathrm{M}$ 이 되도록 하였다. PROP (Sigma-aldrich, Inc., St. Louis, USA) 를 $0.25 \log$ 배수로 희석하여 $1.0 \times 10^{-6} \mathrm{M} ~ 3.2 \times$ $10^{-3} \mathrm{M}$ 의 총 15 단계의 용액을 만들었다. 모든 용액은 $1 \mathrm{~L}$ 유리병에 넣어 $4{ }^{\circ} \mathrm{C}$ 에서 보관하다가 실험하기 전에 꺼내어 사용하였다. PTC 용액과 증류수를 각각 $10 \mathrm{~mL}$ 씩 $10 \mathrm{cc}$ 일회용 주사기에 넣고 가장 낮은 농도부터 시작하여 피검 자 혀의 표면에 $1 \mathrm{~mL}$ 씩 고르게 뿌린 다음 입안에 잠깐 머 금다가 곧 삼키게 한 후, PTC 용액과 증류수 중 쓴맛을 느끼는 용액을 강제로 선택하게 하여 정확히 맞히는 농도
를 역치로 하였다. PROP 용액으로도 같은 방법으로 역치 를 측정하였다.

\section{유전자 분석}

실험 대상들의 말초혈액에서 $10 \mathrm{~mL}$ 의 정맥혈을 채혈하 여 Qiagen FlexiGene DNA kit (Qiagen, Inc., USA)를 이용하여 genomic DNA를 추출하였다. 각 DNA의 양은 분 광계(spectrometer)로 측정하여 $25 \mathrm{ng} / \mu \mathrm{L}$ 로 균일하게 희 석시켰으며, agarose gel 전기영동기를 이용하여 DNA의 질을 알아보았다.

PTC 유전자의 coding region을 특이적으로 증폭할 수 있는 primer들을 제작하여 다음과 같은 조건으로 실험을 수행하였다. 각 polymerase chain reaction(PCR)은 25 ng template genomic DNA, $2.5 \mu \mathrm{L} 10 \times \mathrm{PCR}$ reaction buffer, 1.5 2 $\mathrm{mM} \mathrm{MgCl}_{2}, 0.2 \mu \mathrm{M}$ dNTP, $15 \mathrm{pmol}$ 양쪽 primers, 0.75 u Taq DNA polymerase (5 unit/ $\mu \mathrm{L}$, Applied Biosystem Co., USA), 그리고 $\mathrm{dH}_{2} \mathrm{O}$ 를 넣어 최종 부피를 $25 \mu \mathrm{L}$ 로 맞춘 후 잘 섞은 다음 반응을 시행하였다. 각 $\mathrm{PCR}$ cycle은 $95^{\circ} \mathrm{C}$ 에서 2 분간 denaturation시킨 후, $94^{\circ} \mathrm{C}$ 에서 30초, 각 primer들의 $\mathrm{Tm}$ 온도에 따라 30 초, $72^{\circ} \mathrm{C}$ 에서 1 분간의 조건으로 35 cycles, 그리고 $72^{\circ} \mathrm{C}$ 에서 10 분으로 최종 합성하였다.

$5 \mu \mathrm{L}$ 의 PCR산물은 1.5\% agarose gel에 전기영동을 수 행하여 PCR 증폭여부 및 크기를 확인하였다. 증폭된 PCR products의 경우, 3 U exonuclease I(USB Co., USA)와 $0.3 \mathrm{U}$ alkaline phosphatase (USB Co., USA)를 넣어 섞 은 후, $37^{\circ} \mathrm{C}$ 에서 1 시간 incubation 시킨 후, $80^{\circ} \mathrm{C}$ 에서 15 분간 처리, direct sequencing의 주형으로 이용하였다. PCR product에 대한 염기서열 결정은 $\mathrm{ABI} 3130 \mathrm{XL}$ 자동염기서 열 분석기를 이용하며, DNA Sequencing Analysis software (ver.5.0)로 분석하였다.

유전자 변이 분석은 LASERGENE-SeqMan 및 PHRED/ PHRAP/CONSED software suite를 이용하였다. 각 유전자 에 대한 일배체형은 동형접합체(homozygotes)나 PHASE 2.0.2 프로그램을 이용하여 추론하였다.

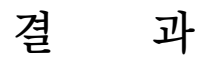

정상인 75명에서 PTC에 대한 미각 역치는 양극성(bimod$\mathrm{al}$ )의 분포를 나타내었으며, PTC 농도 $4.27 \mathrm{mM} / \mathrm{L}$ (13번 용액에 해당)를 기준으로 대상이 양분되는 양상을 나타내었 다(Fig. 1). 기준 농도보다 약한 농도에서 쓴맛을 느꼈던 사 람을 미각인(taster)으로, 그 이상의 강한 농도에서 맛을 느 
Fig. 1. Distribution of genotypes for the TAS2R38 gene by PTC threshold. Distribution of taste threshold of PTC showed significant bimodality with cut-off value of $4.27 \mathrm{mM} / \mathrm{L}$ (dotted line) that separates the group of tasters from the group of non-tasters. Nontasters defined by PTC threshold test were exactly in accordance with AVI homozygous by genotyping tests. PTC: phenylthiocarbamide, PAV: proline, alanine, valine, AVI: alanine, valine, isoleucine.
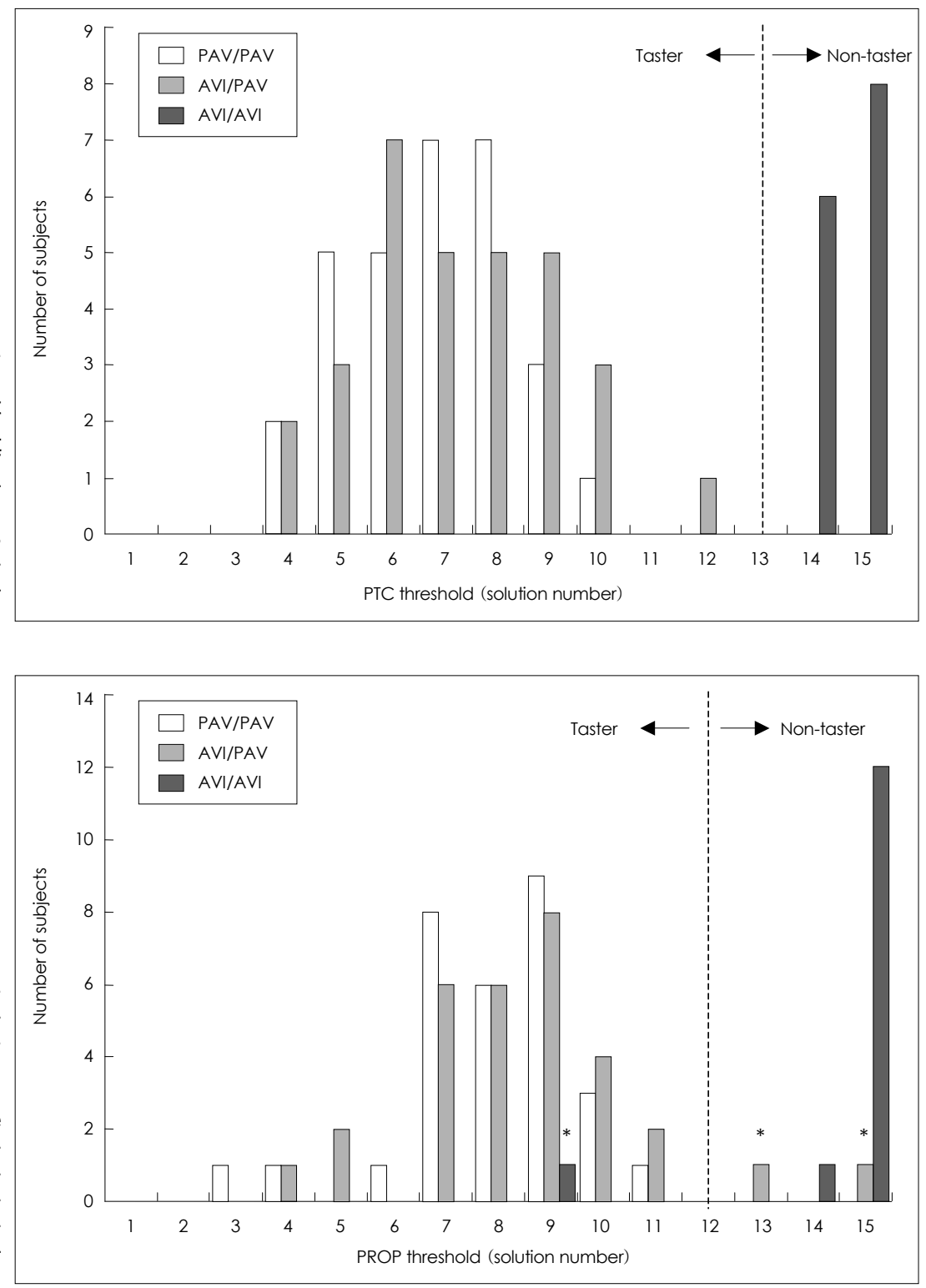

Fig. 2. Distribution of genotypes for the TAS2R38 gene by PROP threshold. Distribution of taste threshold of PROP showed significant bimodality with cut-off value of 0.56 $\mathrm{mM} / \mathrm{L}$ (dotted line) that separates the group of tasters from the group of non-tasters. There was strong concordance between taster status defined by PROP threshold and genotypes, but there were three exceptions (asterisk). PROP: 6-n-propylthiouracil, PAV: proline, alanine, valine, AVl: alanine, valine, isoleucine.

Table 1. Correlation between PTC and PROP thresholds

\begin{tabular}{lcccc} 
& PTC & Taster & Non-taster & Total \\
\hline Taster & 59 & 1 & 60 \\
Non-taster & 2 & 13 & 15 \\
\hline Total & 61 & 14 & 75
\end{tabular}

PTC: phenylthiocarbamide, PROP: 6-n-propylthiouracil

끼거나 전혀 느끼지 못했던 사람을 미맹인(non-taster)으로 분류하였다. $\mathrm{PROP}$ 에 대한 미각 역치 또한 $\mathrm{PROP}$ 농도 0.56 $\mathrm{mM} / \mathrm{L}$ (12번 용액에 해당)를 기준으로 양극성 분포를 보였 다(Fig. 2). PTC와 PROP를 이용한 미맹검사에서 72명이 일치하였고 3명에서 일치하지 않았다. 일치하지 않았던 사람 중 한 명은 $\mathrm{PTC}$ 에 대해 미맹인이었지만, $\mathrm{PROP}$ 에 대해서
Table 2. TAS2R38 genotype groups

\begin{tabular}{cc}
\hline Genotype & No. of subjects \\
\hline PAV/PAV & $30(40 \%)$ \\
PAV/AVI & $31(41 \%)$ \\
AVI/AVI & $14(19 \%)$ \\
\hline Total & $75(100 \%)$ \\
\hline
\end{tabular}

PAV: proline, alanine, valine, AVI: alanine, valine, isoleucine

는 미각인으로 나타났고, 2명은 반대로 나타났다(Table 1). TAS2R38 유전자 분석 결과 PAV/PAV형이 $40 \%, \mathrm{PAV} /$ AVI 형이 41\%, AVI/AVI형이 19\%로 나타났다(Table 2). PTC 역치 검사와 TAS2R38 유전자 분석 결과의 일치율을 비교해 보았을 때 PTC 역치 검사상 미맹인이었던 사람은 모 두 $(100 \%)$ 유전자형이 AVI/AVI형임을 알 수 있었다(Fig. 
1). $\mathrm{PROP}$ 역치 검사와 TAS2R38 유전자 분석 결과의 일 치율을 비교해 보았을 때, 72명에서는 일치하였으나, 3명 에서는 일치하지 않았다(Fig. 2).

\section{고 찰}

미각 장애 여부와는 관계없이 PTC의 쓴맛을 느낄 수 있 느냐 없느냐에 따라 미각인과 미맹인으로 양분할 수 있으 며, 미맹 검사는 1930 년대에 처음 보고된 인간의 화학감각 에 대한 가장 오래된 유전학적 연구로써 멘델의 유전법칙을 따르는 것으로 알려져 있다. ${ }^{1)}$ 미맹 여부는 음주, 흡연 등 의 생활 습관이나 음식을 선택하는 데 영향을 미쳐서 건강 과 밀접한 연관이 있는 것으로 밝혀졌다. 또한 간질, 정신분 열증 환자에서 미맹인의 빈도가 높다는 보고가 있으며, 갑상 선 질환과는 밀접한 연관이 있는 것으로 알려져 있다. ${ }^{1,9,11)}$

쥐를 이용한 동물 실험에서 $\mathrm{PTC}$ 가 호흡 곤란과 폐부종, 흉막삼출을 야기할 수 있음이 보고되었다. 그러나 사람에 서는 극소수에서 구토 증상을 나타낸 외에는 특별한 독성 이 보고된 바 없어 종에 따라 PTC에 대한 감수성이 다른 것으로 추정하고 있다. ${ }^{6)}$ 쥐 실험에서 독성이 발견된 농도 를 사람의 몸무게로 환산하면, 본 연구에서 사용된 농도의 10 20배 이상에 해당하며, 본 연구에 참여한 자원자 중 독성 반응이나 부작용이 나타난 경우는 한 명도 없었다. 그 러나 미각인은 아주 묽은 농도에서 맛을 느끼므로 PTC 섭 취량이 미미하지만, 미맹인의 경우 검사 과정에서 많은 양 의 PTC를 섭취할 수 있으므로 주의를 요하며, 너무 과량을 맛 보게 한다든지, 반복된 검사는 피하는 것이 좋을 것이다.

$\mathrm{PTC}$ 에 대한 독특한 맛 반응이 무엇 때문인지를 알기 위 해 여러 가지 쓴맛을 내는 화학물질들로 검사를 한 결과 $\mathrm{N}-\mathrm{C}=\mathrm{S}$ 구조를 가진 화학물질들이 높은 상관 관계를 보 인다는 것을 알게 되었고, ${ }^{2,3)}$ 미맹인은 혀에 $\mathrm{N}-\mathrm{C}=\mathrm{S}$ 구조 를 인식하는 수용체가 없을 것이라고 보고된 바 있다.5) 그 중에서도 $\mathrm{PROP}$ 는 맛 반응이나 전기생리 반응이 $\mathrm{PTC}$ 와 거의 유사하며, 유황 냄새가 없고 갑상선 치료약으로 쓰이 고 있기 때문에 안전한계가 잘 밝혀져 있는 장점으로 인하 여 대부분의 미맹 연구에서 PTC를 대체하게 되었다. ${ }^{1-6)}$

$\mathrm{PTC}$ 미맹 검사는 $\mathrm{ABO}$ 혈액형 다음으로 가장 많은 연 구된 유전학 분야이지만 최근에야 염색체 $7 \mathrm{q}$ 에 위치한 TAS2R38이 PTC 미맹에 관련된 유전자임이 밝혀졌다. Kim 등 ${ }^{8)}$ 은 TAS2R38 유전자에서 염기쌍(base pair) 145, 785, 886위치에 세 개의 SNP를 발견하였다. 이 유전자의 SNP 의 조합으로 생성된 일배체형 (haplotype) 들은 아미노산 변 화에 따라 이름을 붙여 부르며, 가장 많은 일배체형은 PAV
와 AVI의 두 가지 형태이다. ${ }^{8-10,13)} \mathrm{PAV} / \mathrm{PAV}$ 동종접합형 이 $\mathrm{PTC} / \mathrm{PROP}$ 의 맛에 가장 민감하고, $\mathrm{AVI} / \mathrm{AVI}$ 동종접합 형이 가장 둔감하며, PAV/AVI 이종접합형이 중간 정도의 민감도를 보인다고 하였다. ${ }^{7,14}$ 저자들은 선행연구에서 미맹 인은 유전자형이 AVI/AVI 동종접합형, 미각인은 $\mathrm{PAV} / \mathrm{PAV}$ 동종접합형이나 PAV/AVI 이종접합형으로, 표현형과 유전 자형 간에 밀접한 관계가 있다고 보고한 바 있다. ${ }^{11)}$

$\mathrm{PTC}$ 및 $\mathrm{PROP}$ 에 대한 미맹 여부와 유전자형과의 일치 정도에 대한 연구는 Bufe 등ㄱㅇㅣ 32 명을 대상으로 한 보고 가 유일하다. 이들은 PAV/PAV, PAV/AVI, AVI/AVI의 유전자형을 가진 세 그룹에서 $\mathrm{PTC}$ 및 $\mathrm{PROP}$ 의 농도에 따 라 느끼는 맛의 강도를 연구하였는데, $\mathrm{PTC}$ 는 유전자형에 따라 맛을 느끼는 강도가 뚜렷한 차이를 나타내는 데 비해 $\mathrm{PROP}$ 는 그렇지 않았다고 하였다. 저농도에서는 PTC와 PR$\mathrm{OP}$ 에 대한 반응이 거의 유사했으나, 고농도의 $\mathrm{PROP}$ 에서는 일치하지 않는 것으로 보아 $\mathrm{PROP}$ 에 대한 초역치 민감도 는 다른 유전적 또는 환경적 영향을 받을 가능성을 시사하 며, $\mathrm{PROP}$ 가 PTC의 완전한 대용품이 될 수 없다고 하였다. ${ }^{7)}$ 저자들은 80년 전부터 사용되어온 PTC와 현재 가장 많이 사용되고 있는 $\mathrm{PROP}$ 를 이용한 미맹 검사의 일치율이 어 느 정도인지 알고자 하였고, 최근 알려진 미맹 유전자형과 는 어떤 검사 방법의 일치율이 높을까 궁금하여 본 연구를 시작하였다.

본 연구 결과 미맹의 표현형을 검사하는 방법으로 $\mathrm{PTC}$ 미맹 검사와 $\mathrm{PROP}$ 미맹 검사에서 모두 양극성 분포를 나 타내어 미각인과 미맹인으로 양분되는 양상을 나타내었으 며, 대상 75 명 중 72 명에서 결과가 일치하였고 3 명에서는 일치하지 않았다. 일치하지 않았던 사람 중 한 명은 PTC 에 대해 미맹인이었지만, $\mathrm{PROP}$ 에 대해서는 미각인으로 나 타났고, 2명은 반대로 나타났다(Table 1). 미맹의 유전자 형 검사에서 TAS2R38 유전자 분석 결과 PTC 미맹검사의 표현형과 TAS2R38 유전자형의 일치율은 $100 \%$ 였던 반면, $\mathrm{PROP}$ 검사와의 일치율은 $96 \%(72 / 75)$ 로 4\%(3/75)에서 일치하지 않는 것을 알 수 있었다(Fig. 2). 일치하지 않았던 3 예는 모두 9 번 용액 이상의 고농도의 $\mathrm{PROP}$ 에 대한 반응 에서 유전자형과 다른 반응을 나타내었는데 이는 Bufe 등 7$)$ 의 보고가 일치되는 소견이다.

미맹이란 특정 농도 이상의 PTC에 대해 맛을 못 느끼는 사람으로 정의한 것이 아니고, 대상군이 양극성 분포를 이 루는 농도를 기준으로 미각인과 미맹인으로 분류하여 왔기 때문에 구분의 기준이 되는 농도는 보고마다 매우 다양하다. 그러므로 기준점을 어떻게 정하느냐에 따라 표현형과 유전 자형 간의 일치율이 변할 수는 있다. 그러나 본 연구 결과, 
$\mathrm{PROP}$ 보다는 PTC 미맹 검사가 유전자형과 일치율이 더 높은 것을 알 수 있었다.

결론적으로 $\mathrm{PTC}$ 와 $\mathrm{PROP}$ 를 이용한 미맹검사는 $96 \%$ 의 높은 일치율을 보였지만 소수에서는 일치하지 않았다. PTC 역치 검사에 의한 미맹과 AVI/AVI 유전자형과의 일치율은 $100 \%$ 로, PROP 검사와의 일치율인 $96 \%$ 보다 높게 나타나 $\mathrm{PTC}$ 를 이용한 미맹검사가 $\mathrm{PROP}$ 보다 더 신뢰성 높은 검사 임을 알 수 있었다.

\section{Acknowledgments}

This work was supported by the grant of Research Institute of Medical Science, Catholic University of Daegu (2006).

\section{REFERENCES}

1) Guo SW, Reed DR. The genetics of phenylthiocarbamide perception. Ann Hum Biol 2001;28 (2):111-42.

2) Barnicot NA, Harris H, Kalmus H. Taste thresholds of further eighteen compounds and their correlation with P.T.C thresholds. Ann Eugen 1951;16(2):119-28.

3) Lawless HT. A comparison of different method used to assess sensitivity to the taste of phenylthiocarbamide (PTC). Chemical Senses 1980 5:247-56.

4) Scott TR, Giza BK, Yan J. Electrophysiological responses to bitter stimuli in primate cortex. Ann N Y Acad Sci 1998;855:498-501.
5) Fischer R, Griffin F. Pharmacogenetic aspects of gustation. Arzneimittelforschung 1964;14:673-86.

6) Wheatcroft PE, Thornburn CC. Toxicity of the taste testing compound phenylthiocarbamide. Nat New Biol 1972;235 (55):93-4.

7) Bufe B, Breslin PA, Kuhn C, Reed DR, Tharp CD, Slack JP, et al. The molecular basis of individual differences in phenylthiocarbamide and propylthiouracil bitterness perception. Curr Biol 2005;15 (4):322-7.

8) Kim UK, Jorgenson E, Coon H, Leppert M, Risch N, Drayna D. Positional cloning of the human quantitative trait locus underlying taste sensitivity to phenylthiocarbamide. Science 2003;299 (5610):1221-5.

9) Kim UK, Drayna D. Genetics of individual differences in bitter taste perception: lessons from the PTC gene. Clin Genet 2005;67 (4) :275-80.

10) Wooding S, Kim UK, Bamshad MJ, Larsen J, Jorde LB, Drayna D. Natural selection and molecular evolution in PTC, a bitter-taste receptor gene. Am J Hum Genet 2004;74 (4) :637-46.

11) Ye MK, Shin TH. Relationship between PTC Genotype and Taste Phenotype in Normal Volunteers. Korean J Otorhinolaryngol-Head Neck Surg 2008;51 (12):1124-8.

12) Harris H, Kalmus H. The measurement of taste sensitivity to phenylthiourea. Ann Eugen 1949;15 (1):24-31.

13) Cannon DS, Baker TB, Piper ME, Scholand MB, Lawrence DL, Drayna DT, et al. Associations between phenylthiocarbamide gene polymorphisms and cigarette smoking. Nicotine Tob Res 2005;7 (6): 853-8.

14) Duffy VB, Davidson AC, Kidd JR, Kidd KK, Speed WC, Pakstis AJ, et al. Bitter receptor gene (TAS2R38), 6-n-propylthiouracil (PROP) bitterness and alcohol intake. Alcohol Clin Exp Res 2004;28 (11): 1629-37. 